\title{
A Tribute to Chief Raphael Ige Ibigbami (1938-2020): The Father of Modern Nigerian Ceramic Art
}

\author{
Olawole Famule \\ Department of Visual Arts \& Art History \\ University of Wisconsin-Superior \\ ofamule@uwsuper.edu
}

Awo kì kú, Awo kì rùn

Awo ńpa'pòódà $n i$

B'Áwo bá p'èhìndà tán

K'ẹni máse sè' dárò Awo

The knowledgeable ones do not die and do not become rotten

They only transition to the spiritual realm of ancestors

Therefore, when a knowledgeable one transitioned

Let no one mourn but rather celebrate the transition

İyẹ rẹ Ifá dirge for a deceased Babaláwo, Ifá diviner ('Father of ancient wisdom')

We celebrate the life of our knowledgeable and well accomplished retired Ceramics Professor at the Obafemi Awolowo University, Ile-Ife, Nigeria, Chief Raphael İgè Ibigbami, who transitioned to the realm of ancestors on August 26, 2020. 


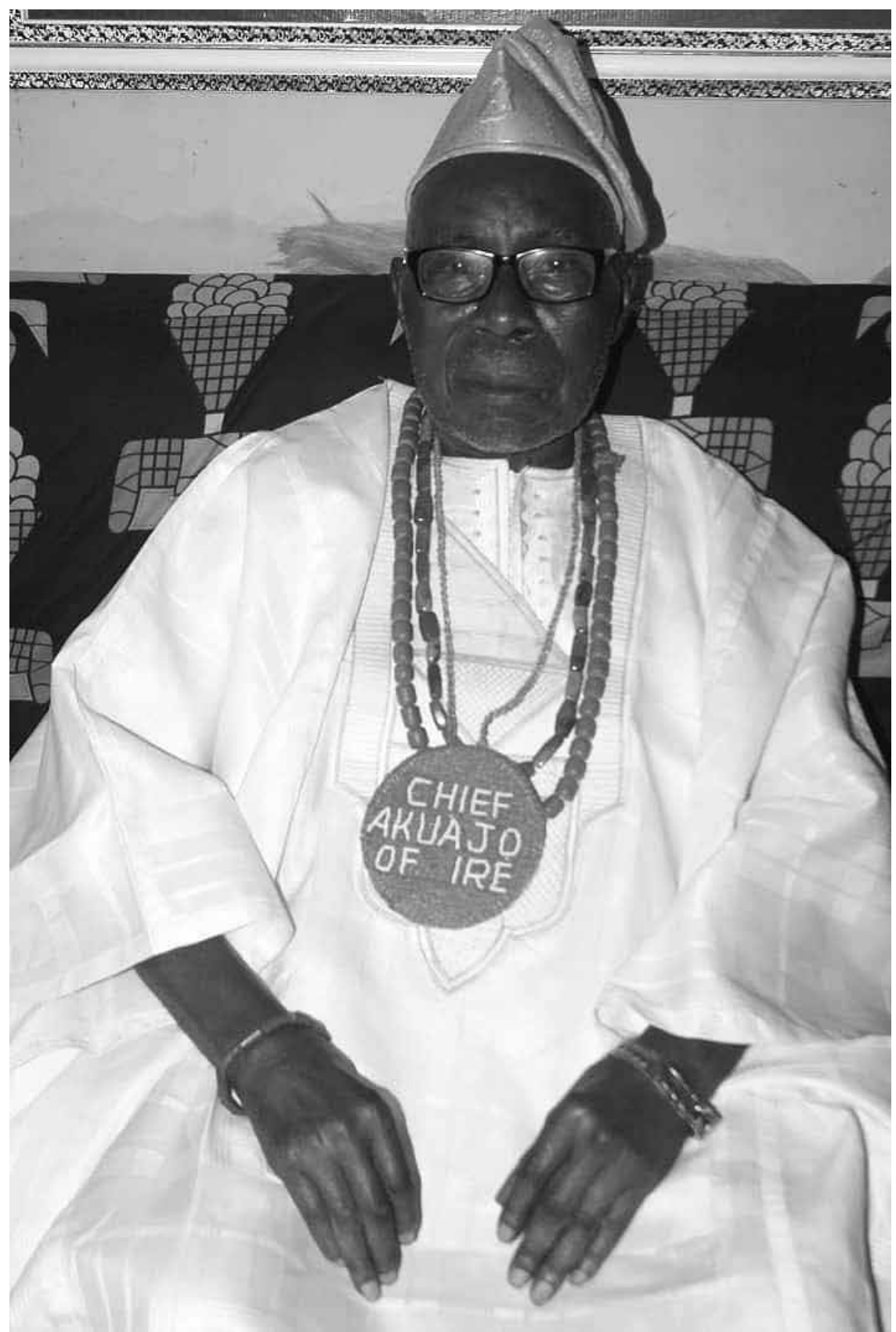

FIG. 1. Chief Raphael Ige Ibigbami, The Akuajo of Ire Ekiti 
Ibigbami was so loved and respected by his colleagues and students whose enormous academic achievements will forever remain indelible. He was born İgè, a Yoruba orúko àmútọ̀runwá (literally, 'name brought from heaven') for any baby who came out of the womb with feet first. For this reason, like every İgè, Chief Ibigbami assumed at birth, the Yoruba orikì (praise chant) for İgè (below):

İgè àdùnbí, a gbó lẹnu bí agogo

Igè kò rojú ìá, ojú baba ló ro

İè ibá rojú ìyá, kò bá tí kẹsè sita

İgè, one whose birth was easy for its mother (an ironic way of saying İgè's

birth was painful for the mother), and as unique as the enduring sounds of a bell

İgè did not think of its mother, except about the father

Had it thought about its mother, İgè would not have come out of the mother's womb with feet first

Ibigbami was born on May 25, 1938 in Ire-Ekiti, Oye Local Government in Ekiti State to the Family of Pa. Mathias Ibigbami and Elizabeth Osatomola Ibigbami, both of blessed memories.

For over two months following the death of Chief Ibigbami and after an encomium entitled "Ode to 'father' of modern Nigerian ceramics" by Tunde Nasiru appeared in his honor on 14 October 2020 in The Nation (a Nigeria's newspapers). ${ }^{1}$ I have been asked if I could write a tribute to him that could be accessible to a larger academic audience. However, two months passed by, I still had not commenced on the task. I was confronted with a two-fold quandary: The first was where do I start the tribute? Secondly, what would I include or leave out? The reason being that it would take far more than one piece of tribute, to catalog all the humongous accomplishments Chief Ibigbami had delivered for the Yoruba Studies and the academic discipline of Modern Nigerian art. This also includes moving the field of Contemporary African art practice to its current prominent level of recognition across the world.

In attempting to compose an all-encompassing and well-deserved tribute to the late sage Ibigbami, I will focus on the two major factors that have shaped his journey to becoming an authority in the academic field of Modern Nigerian art, particularly his chosen specialty in Ceramics.

1 Tunde Nasiru, "Ode to 'father' of modern Nigerian ceramics," In The Nation, 14 October 2020 https://thenationonlineng.net/ode-to-father-of-modern-nigerian-ceramics/ 


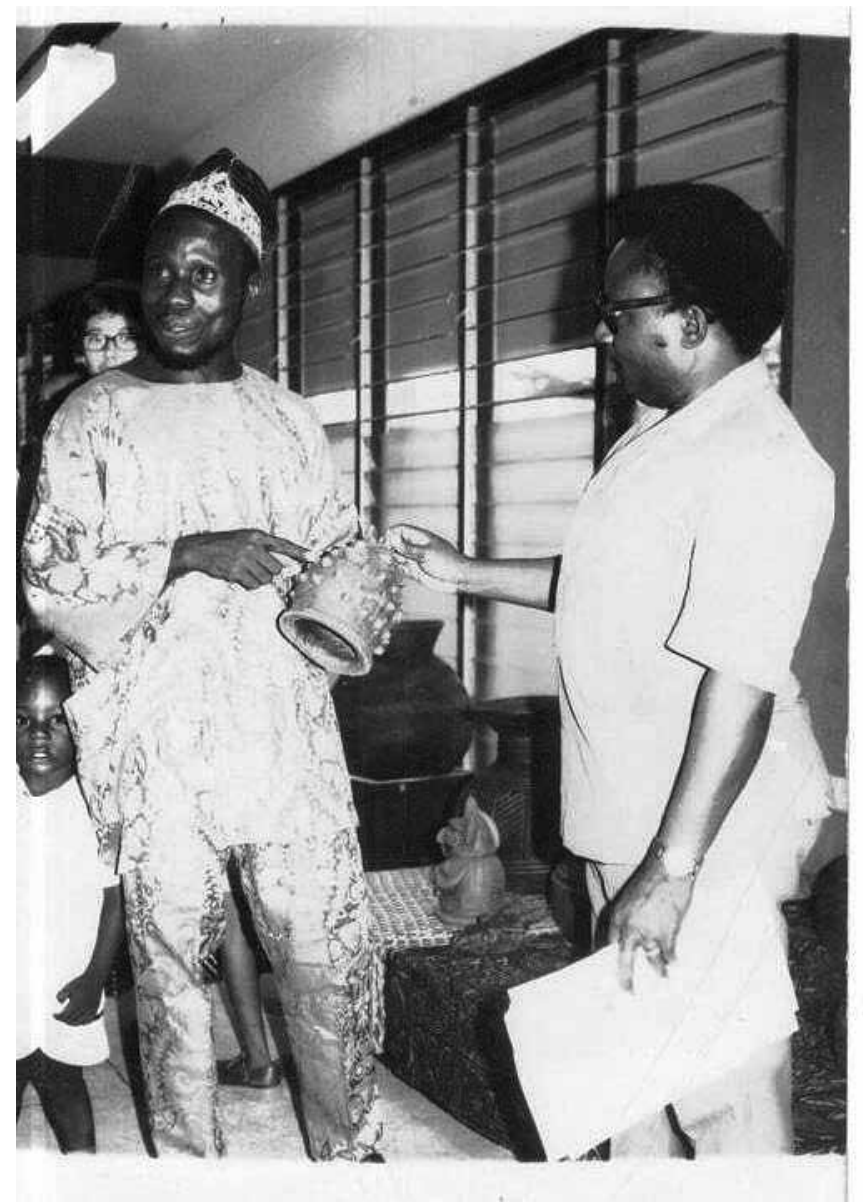

FIG. 2. Ibigbami at an exhibition of his works in the late 1970s-early 1980s

The first had to do with the Ibigbami's birth and his humble background. The second was an offshoot of establishment of the then Institute of African Studies at the University of Ife (now Obafemi Awolowo University) in 1962: to actualize the cultural aspect of the University's Motto, "for learning and culture" and Mission, "to nurture a teaching and learning community; advance frontiers of knowledge; engender a sense of selfless public service; and add value to African culture." This was a relevant factor since the appointment of Ibigbami, at the institute in 1972 gave him the rare opportunity and 
needed conducive environment to unleash his best, to become the 'Father' of Modern Nigerian Ceramic art.

A closer look at these two key factors (specified above), which shaped who Ibigbami would later become an outstanding academic, seems in order. I begin with the first factor, the unique circumstances surrounding Ibigbami's birth and his humble background. After several miscarriages, Ibigbami's mother, Èyé Elizabeth Òșàtómọ̀la Ìbígbàmí of blessed memory, fell into labour on her way home from a long-distance trek, holding on to Ibigbami's feet as he came out from her womb. As frightful as this condition was, this also occurred on a rainy day, aggravating Mama's unimaginably dreadful tasks. Dealing with the excruciating labor pain on the one hand and walking a long distance with her entire clothing soaked in the rain on the other hand. However, the joy of it was that the rain gave the soon to be delivered baby Ibigbami an additional birth name beside Ìgè (breech baby), Abéjidé ('one whose birth was accompanied by a rain downpour'). At this time, Ibigbami was the first of three children that survived out of 13 pregnancies. These mysterious circumstances of his birth created an unparalleled cordial relationship between Ibigbami and his mother that could best be explained using the 'Attachment theory': how the parent-child relationship emerges and influences the child's subsequent development. ${ }^{2}$

Since Ibigbami's mother with whom he had consistently had a close bond and inseparable attachment right from birth was a traditional artist who specialized in kijìpá weaving, ${ }^{3}$ using the vertical loom, Ibigbami was exposed to traditional Yoruba art practice at an early age. Ibigbami succinctly affirmed this when he explained, "My mother was a very hard-working woman, who used to weave my school uniform in her loom. In those days, there was no tape rule or any measurement gauge, but they would use the hand, the gap between the thumb and the first finger as a token of measurement."4

2 The English psychiatrist John Bowlby (1969/1982) and American psychologist Mary Ainsworth (1967), authors of the 'Attachment theory', define it ('Attachment theory') as a deep and enduring emotional bond between two people in which each seeks closeness and feels more secure when in the presence of the attachment figure. The theory explains how the parent-child relationship emerges and influences subsequent development. For further readings on 'Attachment theory', see J. Bowlby, Attachment and Loss (Volume 1): Attachment, New York: Basic Books (1969) and M. Ainsworth, Infancy in Uganda: Infant Care and the Growth of Love, Baltimore, MD: Johns Hopkins University Press (1967).

3 Kijìpá is the earliest known indigenous Yoruba handwoven fabric traditionally woven by Yoruba women on the vertical broad looms; while their male counterparts weave the aṣo òkè (also aṣo òfì) using the horizontal narrow looms.

4 Olajide Omojolomoju, "Contentment was watchword in our days - Pa Ibigbami”: Interview with Chief Raphael Ige Ibigbami, In LEADERSHIP Newspaper, 2018, 
That rare opportunity of being the first child of a traditional artist mother gave Ibigbami the needed artistic background and eye-opener that would prepare him ahead for the task of becoming the "most authentic ceramics art teacher Nigeria has ever produced." ${ }^{5}$ In fact, Ibigbami would be forever celebrated as a distinguished teacher of professors and multitudes of other Ife Art School graduates who have passed through him and are breaking grounds in their respective endeavors, other than lecturing, all over the globe today. I will not venture to identify them by names not only because they are too numerous to count, but also for lack of enough time and space to do so here.

Equally connected with this first factor responsible for Ibigbami's remarkable accomplishments was his background. Ibigbami had a very humble upbringing, an invaluable credential that played an important part in catapulting him to the highest pinnacle in his career as a respectable don, who retired as Associate Professor of Fine Arts at the Obafemi Awolowo University, Ile-Ife in 1990. From Ibigbami himself, we now know with certainty that he grew up in a typical traditional Yoruba setting, as he recalled vividly his experience as a young boy:

In those days, when I was young, we used to play in the evening under the moon. We also use to play 'ayo' but in those days, you must not play it in the night. The feast in my place was Ogun festival, I am from Ile Ogun and we must know how to greet and extol the god of iron. ...Growing up was unlike nowadays; it was really a typical rural setting where children were very obedient to their parents; where the father would call the son, and the son would answer ' $E e$ oo', because there was nothing like 'sir' in those days. I used to follow my father to the farm, because he was a farmer who cultivated yam, maize and cassava. Then a child's capacity and prowess was measured by how many heaps he could make, hoe, dig or cultivate on the farm in a day. 'Mo ti ko igba oran (ebe)' (I have made 200 heaps); 'Mo ti ko ogórun-ún oran (ebè)' (I have cultivated 100 heaps); etc. That was the situation in those days. But I didn't keep long in that situation, because my father taught me the Yoruba and the English alphabets when I was very young. ${ }^{6}$

Ibigbami started schooling at the age of four in 1942 at St. Gregory Catholic Primary School, Ire-Ekiti. He completed his Primary School Education 10

accessible at: https://leadership.ng/contentment-was-watchword-in-our-days-pa-ibigbami/

5 Tunde Nasiru, “Ode to 'father' of modern Nigerian ceramics," In The Nation, 14 October 2020

6 Olajide Omojolomoju, "Contentment was watchword in our days - Pa Ibigbami”: Interview with Chief Raphael Ige Ibigbami, In LEADERSHIP Newspaper, 2018. 
years later in 1953, earning the Standard Six Certificate. That landed him an immediate teaching job at a neighboring school the following year in 1954 at the age of 16 years. After teaching for eight year with his Standard Six Certificate, Ibigbami proceeded to Grade III Teachers College in St. Augustine R.C.M. Oye Ekiti in 1962 and had his Grade III Teachers Certificate in 1963, posted to Roman Catholic Primary School, Ijare as a headmaster. He sat for the General Certificate of Education (GCE) in 1965 and passed his papers, which qualified him to become a tutor in Igbara Oke Anglican Grammar School less than a year. He was admitted to the Ahmadu Bello University, Zaria in 1965 to study Fine Arts. On completion of the B.A. Fine Arts degree with a major in pottery/ceramics in 1969, he was given a scholarship to pursue his master's degree programme the same year (1969).

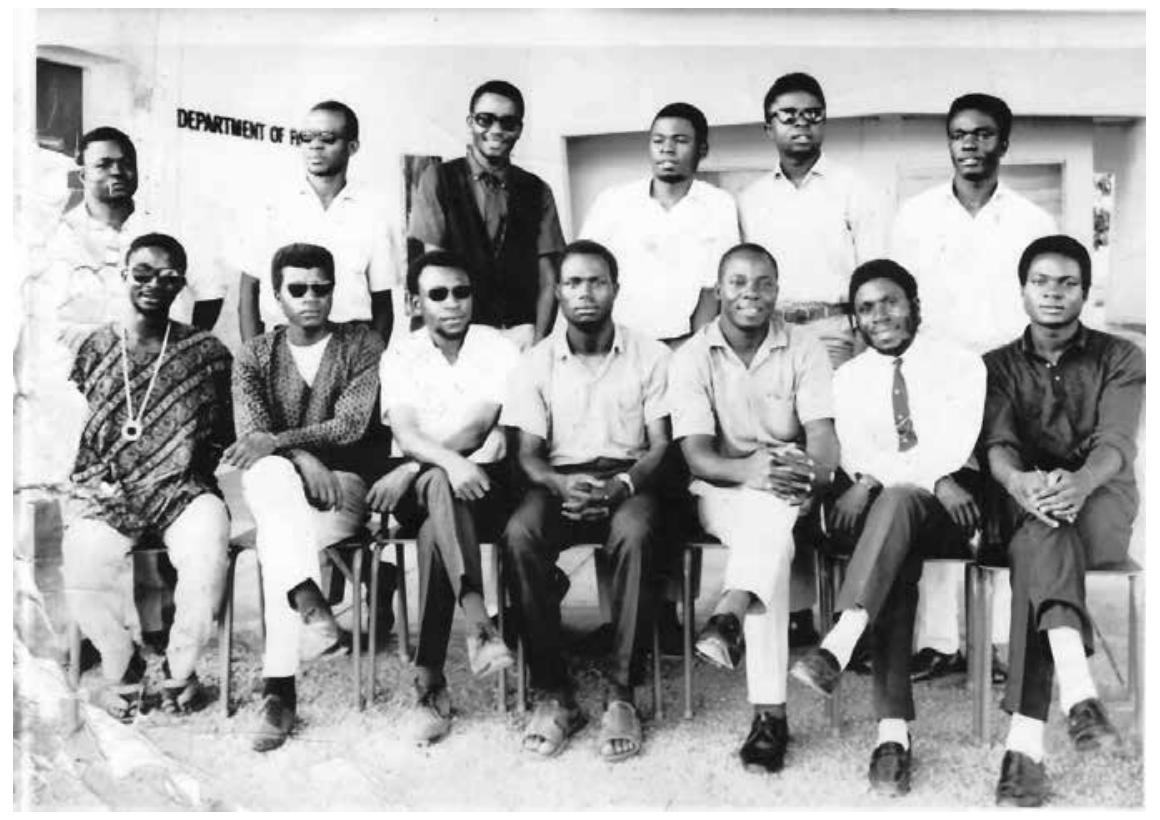

FIG. 3. Ibigbami (from L to R: seated sixth to the last) and his Fine Arts undergraduate student-colleagues at the Ahmadu Bello University, Zaria. c. 1968-69 
It should be noted that Ahmadu Bello University was the first in Nigeria to offer the master's degree programme in fine arts and Ibigbami was the very first admitted postgraduate student. He completed the master's degree studies two years later, thus, becoming the first person to be awarded the Master of Fine Arts (MFA) degree in Nigeria in $1971 .^{7}$

The second and last factor responsible for Ibigbami's impressive academic attainments. It centered on the establishment of the then Institute of African Studies at the University of Ife (now Obafemi Awolowo University) in 1962, which employed him in its art and art history section in 1972. As a result, Ibigbami found there the rare opportunities that facilitated and drawn out the best in him, and made him the 'Father' of Modern Nigerian Ceramic art. To delve deep into this factor, it is necessary to provide some historical background of the Institute with emphasis on its art and history section, which started offering service courses in Fine Arts in 1969 and a full degree Fine Arts programme beginning 1973/74. Later transferred to the Faculty of Arts in January 1976 when a substantive Department of Fine Arts was created. ${ }^{8}$

Established when the University of Ife (now Obafemi Awolowo University) was founded in 1962, the Institute of African Studies at Ife was designed to actualize the "culture' related rationale for founding the University as evinced in Its Motto, "for learning and culture" and Mission, "to...add value to African culture." Hence, as affirmed by Michael Crowder, the Institute's director from 1968-71, ${ }^{10}$ the Institute of African Studies at Ife "primarily concerned with research into the culture of tropical Africa." 11 The Institute was organized into four sections, namely art and art history, archaeology, performing arts, and African languages with their research projects and inter-disciplinary conferences "sponsored with the aid of a Ford Foundation grant of $\$ 150,000$ made in 1963."12 For the needed manpower to carry out the Institute's aforementioned goal of researching into the "African culture," 15 Research Fellows were hired as of the 1969 session, out of which the Institute's art and art

7 See Olajide Omojolomoju, "Contentment was watchword in our days - Pa Ibigbami": Interview with Chief Raphael Ige Ibigbami, In LEADERSHIP Newspaper, 2018.

8 See Babatunde Lawal, "The Ife Art School”, In Evolution in Nigerian Art Series 2: The Ife Art School (1984), p. 8.

9 For further reading relating to the Motto and Mission of the University of Ife (now Obafemi Awolowo University), see the University website: https://oauife.edu.ng/

10 See "Michael Crowder," In Journal of African History, Vol. 29. No. 3, i-ii (1983: $1-2)$.

11 See "Notes and News," In Africa: Journal of the International Institute, Vol. 41, no. 1 (1971: 57). Also see Michael Crowder, "Institute of African Studies, Ife", In The Journal of Modern African Studies, Vol. 7 no. 3 (1969: 513).

12 See Michael Crowder, "Institute of African Studies, Ife", The Journal of Modern African Studies, Vol. 7 no. 3 (1969: 514). 
history section enjoyed three. They included J. R. O. Ojo, hired in 1966 and primarily to serve as the Curator of the Institute's two museums, one on the University's campus at Ile-Ife and the other at Osogbo, ${ }^{13}$ and to teach painting and art history. ${ }^{14}$

The other two were Irein S. Wangboje and Agbo Folarin, both hired in 1968 as Research Fellows in the art and art history section. The former taught painting and print making while the latter taught sculpture. ${ }^{15}$ However, 1970 and 1971 marked the turning point in the history of the Institute's art and art history section, when Rowland Abiodun and Babatunde Lawal were hired respectively, as Research Fellows. A turning point indeed, since the two groomed there (at the Institute) were later to become the world's renowned Africanist African art historians. ${ }^{16}$

13 See J.R.O. Ojo, Museum of the Institute of African Studies, University of Ife: A Short Illustrated Guide, Ile-Ife: University of Ife Press, 1969, pp. 1-11.

14 J. R. O. Ojo, B.A. (ABU), MPhil. (London), Dip. Social Anthropology (Edinburgh), was the first to be hired in the art and art history section of the Institute of African Studies at Ife in 1966. For further reading about Professor J.R.O. Ojo, see "OJO, John Rowland Oluwafemi," In Biographical Legacy \& Research Foundation, Nigeria: Blerf's WHO'S WHO IN NIGERIA (online), Edited by Nyaknno Osso https://blerf.org/ index.php/biography/ojo-john-rowland-oluwafemi/. However, the art and art history section (that metamorphosed to today's Fine and Applied Arts department) started teaching art as a major subject for the Faculty of Education's B.Ed. programme in 1969 and a full Fine Arts degree programme beginning 1973/74 session, transferred to the Faculty of Arts in January 1976, when the Institute was defunct, and to the Environmental Design and Management in 1989 following the approval and directive from the National Universities Commission.

15 Irein S. Wangboje, having bagged his B.A (ABU, 1959), MFA (Granbrook Academy of Arts, Michigan, 1963), and Ed.D. (New York University, 1968) degrees, joined the Institute of African Studies at Ife in late 1968 as Research Fellow. He moved to ABU Zaria in 1971 where he later became Professor of Fine Arts, retired as Professor of Creative Arts, University of Benin, Benin City in 1996. For further reading about Professor Wangboje, see "WANGBOJE, Professor Solomon Ona Irein," In Biographical Legacy \& Research Foundation, Nigeria: Blerf's WHO'S WHO IN NIGERIA (online), Edited by Nyaknno Osso, accessible at https://blerf.org/index.php/biography/wangboje-professor-solomon-ona-irein/. On the other hand, Agbo Folarin, Dip. A. D (Central School, London, 1967), M. A and MFA (Howard, 1980 \& 1984), joined the Institute's art and art history section in 1968 as Research Fellow. He rose in rank to Professor of Sculpture and Architectural Design in the same University (OAU), where he retired in 2003/04. For further reading about Professor Folarin, see "FOLARIN, Agbo," In Biographical Legacy $\&$ Research Foundation, Nigeria: Blerf's WHO'S WHO IN NIGERIA (online), Edited by Nyaknno Osso, accessible at https://blerf.org/index.php/biography/folarin-gbo/

16 Professor Rowland Abiodun, author of the groundbreaking and timeless publication, Yoruba Art and Language: Seeking the African in African Art (Cambridge University Press, 2014) and who joined the Institute of African Studies at Ife in 1970, holds B. A. Fine Arts, First Class Honors (ABU, 1969) and M.A. Art History (Toronto, 1969). For 
Prominent among the projects embarked by the Institute, which aided the Research Fellows' tremendous and rapid academic developments, included the following. The Ife Research Project, investigating all aspects of the city of Ife-history, culture, social structure, and economy; the weekly Seminars, where the Institute's Research Fellows had the avenue to make presentations of their research work; Ori Olokun, the Cultural Centre located in the city of Ile-Ife, and the annual Ife Festival of Arts, first held in December 1968 among others. ${ }^{17}$

As all the progress highlighted above were unfolding, the Institute realized quite apparently that there was something indispensable still missing: there was nobody in the art and art history section to start and teach the ceramic courses. Thus, the Institute was in dare need of an academically trained ceramicist, which were incredibly scarce even in United States and the United Kingdom, from where most of the Nigerian university lecturers were recruited at the time. We should recall as earlier mentioned in this write-up, the first university in Nigeria to offer Master's Programme in any area of the Fine Arts at the time was the Ahmadu Bello University, Zaria. Interestingly, Ibigbami was the first person to be admitted there (at ABU), did his Master's Programme in Fine Arts from 1969-71, and was awarded the Master of Fine Arts degree with specialty in Ceramics in 1971.

Sharing the story of his miraculous appointment in the Institute of African Studies at Ife with the writer sometime in 1995, Chief Ibigbami recalled that Professor Rowland Abiodun, a Research Fellow in the Institute's art and art history section at the time, was instrumental. He explained that when Professor Abiodun got the news of his Master of Fine Arts (Ceramics) degree award, the very first in Nigeria at the time, he quickly alerted Michael Crowder, Director of the Institute. The latter immediately arranged with him the job

further reading about Professor Abiodun, see "Rowland O. Abiodun," In Amherst College, Amherst, MA 01002

https://www.amherst.edu/people/facstaff/roabiodun. Conversely, Babatunde Lawal, author of the famous book, The Gelede Spectacle: Art, Gender, and Social Harmony in an African Culture (University of Washington Press, 1997) and who earned B. A. Fine Arts (UNN) and M. A., PhD Art History (Indiana, 1970) joined the Institute in 1970/71 session as Research Fellow. He rose in rank to become the first Professor of Fine Arts at Ife and served as Dean of Faculty of Arts before he retired from the University in the late 1980s. For further reading about Professor Lawal, see "Babatunde Lawal," In Virginia Commonwealth University, School of the Arts, Richmond, VA 23284-3046

https://web.archive.org/web/20140523102325/http://arts.vcu.edu/arthistory/faculty-bio/ babatunde-lawal/

17 See "Notes and News," In Africa: Journal of the International Institute, Vol. 41, no. 1 (1971: 57-58). Also see Babatunde Lawal, "The Present State of Art Historical Research in Nigeria: Problems and Possibilities" (Footnote 1), In Journal of African History (Published by Cambridge University Press), Vol. 18, no 2, 1977, p. 193 (footnote 1). 
interview for the position of Research Fellow in the Institute's art and art history section and the rest is history: Ibigbami joined the University of Ife (now Obafemi Awolowo University) as Junior Research Fellow from 1972-73 session. Through diligence, he rose to the rank of Principal Art Fellow (Reader) in 1982 and retired from the University in 1990 as Associate Professor.

I now consider Ibigbami's landmark at the Ife Art School, where his fame has since exploded not just beyond the Obafemi Awolowo University, Nigeria or Africa, but indeed, across the globe as the "father of modern Nigerian ceramics and pottery art" (to use Babatunde Nasiru's exact words). ${ }^{18}$ In line with the principal concern of the defunct Institute of African Studies at Ife, which was to "research into traditional and modern African culture,"19 and as well, the Ife Art School's three distinct characters: "a re-orientation in art education towards functionalism; the adaptation of indigenous design resources to the needs and requirement of modern times; and the evolution of Nigerian identity for contemporary Nigeria art," ${ }^{, 20}$ Ibigbami built a formidable foundation for Ceramics section that is still as strong as ever today. Owned to his deep knowledge of the traditional African art and culture by the virtue of himself being a Yoruba culture bearer, who was deeply immersed in his indigenous art and cultural beliefs and practices, Ibigbami's pedagogy motivated the students to look within their indigenous traditions, such as the Yoruba philosophies and visual arts and culture for integration in their artistic creative process.

He achieved this using an array of resourceful strategies. First, knowing fully that most Nigeria's ethnic groups, the examples of the Yoruba, Nok, Dakakari and Igbo Ukwu to mention but just a few, are specially gifted in terracotta and pottery traditions. Ibigbami placed a great emphasis on the students' use of indigenous hand-built pottery technique, process, and design elements. He did this by introducing the indigenous pottery techniques into university curriculum and he developed an innovative kiln to fire bisque ware. With the full support from the Department, he directed series of pottery workshops "during which traditional potters work side by side with undergraduates. The aim is not only to transfer traditional skills to student artists, but also to explore new methods of producing traditional pottery without losing any of the

18 See Tunde Nasiru, "Ode to 'father' of modern Nigerian ceramics." The Nation, 14 October 2020.

19 See Michael Crowder, "Institute of African Studies, Ife", In The Journal of Modern African Studies, Vol. 7 no. 3 (1969: 513).

20 See Frank Aig-Imoukhuede, 1984. "Introduction," Evolution in Nigerian Art Series 2: The Ife Art School (1984: 5-6). 
advantages it has over modern metal and plastic substitutes." ${ }^{21}$ The pottery wares resulting from the workshops were exhibited both within and outside the Ife University campus.

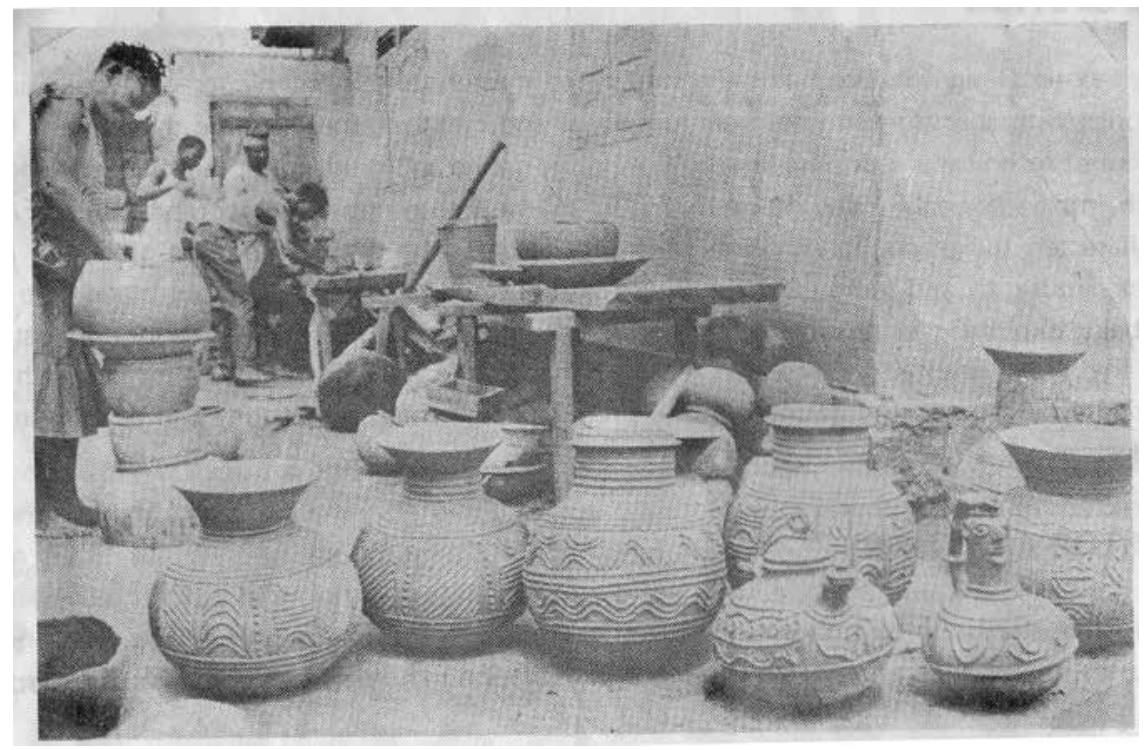

FIG. 4. A Traditional Potter at the Pottery Research Workshop (organized and directed by Ibigbami), Ile-Ife. c. 1974-84

Few among them included the following. Traditional Pottery Styles from the Pottery Workshop, Ife University Library, Ile-Ife, 1973; Pottery from Ife Pottery Workshop, University of Ibadan, Ibadan, 1973; Pottery from Ife Pottery Workshop, National Museum, Lagos, 1974; Ife Pottery Workshop Exhibition, Institute of African Studies, University of Ife, Ile- Ife, 1975; Ife Pottery Workshop Exhibition, Goethe Institute, Lagos, December 8-22, 1976, and Traditional Pottery from Ife Pottery Workshop, University of Benin, Benin City, $1984 .^{22}$

21 See the "Pottery Section," Evolution in Nigerian Art Series 2: The Ife Art School 1974-1984 (1984: 18).

22 I use this medium to say a very big 'Thank you' to Dr. Ola Ibigbami, Chief Ibigbami's son and lecturer in the department of Mental Health at the Obafemi Awolowo University, Ile-Ife, who made available for me his father's unpublished biography. That really, really helped in composing this writeup. Also see "IBIGBAMI, Ige," In Biographical Legacy \& Research Foundation, Nigeria: Blerf's WHO'S WHO IN NIGERIA (online), Edited by Nyaknno Osso: https://blerf.org/index.php/biography/ibigbami-ige/ 


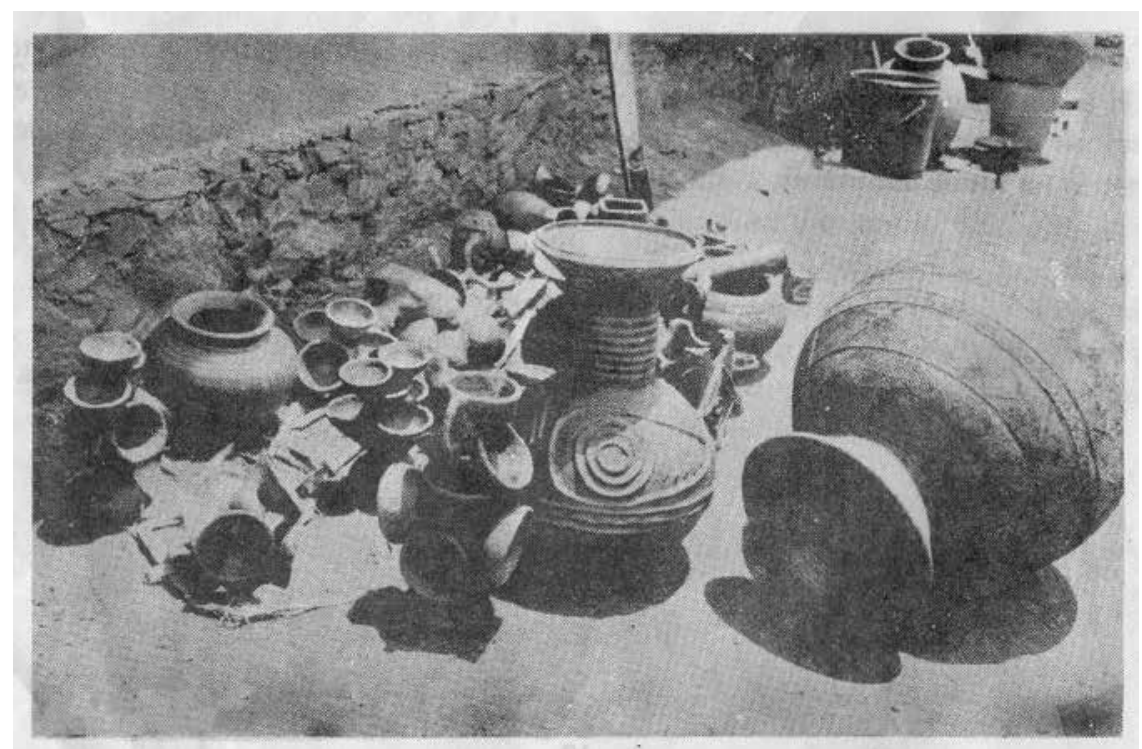

FIG. 5. Pots Produced at the Pottery Research Workshop (organized and directed by Ibigbami), Ile-Ife. c. 1974-84

Correspondingly, he (Ibigbami) recommended that the Department employ as artist-in-residence, Mrs. Felicia Adepelu, a traditional potter from Igbara-Odo, to be providing practical demonstrations of her traditional Yoruba pottery making technique and design skill to the students. ${ }^{23}$ Furthermore, based on his own impressive field experience resulting from his incessant trips to pottery centers all over the Yorubaland, such as Ipetumodu, Ara-Ekiti, Ishan-Ekiti, Igbara-Odo and Ilorin. Ibigbami understood that his students also needed to watch and study the traditional potters at work in their rural pottery centers setting. He believed this would enable them experience and appreciate the actual cultural context in which the potters operate. Thus, by mid 1980s, having established an impressive link with those traditional potters, especially at the pottery centers within a short distance from the University campus in Ile-Ife, Ibigbami "arranged field trips to the village of Ipetumodu where male

23 For further readings on Ibigbami's efforts of encouraging the students of the Ife Art School to familiarize with the African cultural elements as they relate to traditional Yoruba pottery techniques and process for possible adaptation and assimilation in their ceramic art, see Moses A. Akintonde, "Repositioning Ceramic Professionalism in Art Training in Nigerian Tertiary Institution," In Journal of Education and Practice, Vol. 4 no.16 (2013: 140) and Akintonde, Emmanuel Akinde, Oladapo Abiodun, and Adeyinka Okunade, "Outdoor Pottery Sculpture in Ife Art School," In Academic Journal of Interdisciplinary Studies, Vol. 4 no. 3 (2015:226). 
and female students could observe the hand construction and firing methods of Yoruba women potters. ${ }^{24}$ In that way, most students were able to embrace and synthesize their field experience relating to the indigenous pottery techniques and design elements in their own contemporary idea experimentation for cultural identity. ${ }^{25}$ The result was (and is) the distinctive style-product, the 'Pillar Pot', often embellished with high relief sculptural illustrations of an array of Yoruba mythological and/ or religious themes, with which the Ceramic Products of the Ife Art School are known till this day. ${ }^{26}$ This cannot be more revealing in the tons of masterpieces created by most of Ibigbami's former students, particularly Babatunde Nasiru, whose characteristic pottery figure with the head-to-body proportion of ratio 1:3 recalls the traditional Yoruba art convention found mostly in their wooden sculptures. The ère ibeji (figurines for departed twins), in which the heads are disproportionally large compared to the highly compressed rest of the body, is an example.

Others include Moses Akintonde, the master of picturesque pottery sculpture, and Yinka Okunade, whose high taste for Yoruba mythological oriented theme and graphical narrative pottery figure quality recall Akintonde's. However, he (Okunade) is unmatched when it comes to paying attention to minute details, which help push his photorealism idiosyncrasy even to the extreme. His masterwork, the A ó mérin joba (1995), a terracotta high relief sculpture, comes to mind.

While Ibigbami had been celebrated for almost single handedly built the Ife ceramics art programme from the scratch to an enviable status and considered the "most authentic ceramics art teacher Nigeria has ever produced,"27 it must also be added that his legacy and influence has continued to prevail across the entire sectional areas of specialization in the Ife Art School. Some hint on a seemingly example to corroborate this assertion is necessary. Considering his unique pedagogy that drew preponderantly on the Yoruba conception about art as onà or iṣé onà and its essential attributes within the Yoruba cultural context, it is not an overreach or illogical to postulate that Ibigbami was inspirational to the founding of the Onà Group, an art movement formed

24 See Betty LaDuke, Africa: Through the Eye of Women Artists, New Jersey: Africa World Press, Inc. (1991: 18)

25 See Moses Akintunde Akintonde, In "Repositioning Ceramic Professionalism in Art Training in Nigerian Tertiary Institution," In Journal of Education and Practice, Vol.4, No.16, (2013: 140).

26 For further reading on the unique pottery products of the Ife Art School graduates, see Moses Akintonde, Emmanuel Akinde, Oladapo Abiodun, and Adeyinka Okunade, "Outdoor Pottery Sculpture in Ife Art School", In Academic Journal of Interdisciplinary Studies, Vol. 4, no 3 (2015: 222- 230).

27 See Babatunde Nasiru, "Ode to 'father' of modern Nigerian ceramics," In The Nation, 14 October 2020. 
by five graduates of the Ife Art School. The reason for this supposition cannot be more obvious. Just like Ibigbami, the Group has continually been committed to the pursuit of artistic excellence through the assimilation of the traditional Yoruba art concepts and philosophies to construct new realities. This assertion is even more compelling since the founders, Moyo B. Okediji (Ife art school graduate, 1977); Emmanuel O. Filani (Ife art school graduate, 1980); Festus A. Wewe (Ife art school graduate, 1983); Bolaji Campbell (Ife at school graduate, 1984 and 1989), and Babatunde Nasiru (Ife art school graduate, 1985 and 1989), have all passed through Ibigbami, attended his ceramics introductory class, 'Three-Dimension Art: Pottery'. In his well-written compliment to Chief Ibigbami, entitled "Ode to 'father' of modern Nigerian ceramics" (2020), Babatunde Nasiru, one of the Ona Group members who also studied Ceramics with Ibigbami (B.A 1985 and MFA 1989) and whose style and Ibigbami's have been described as "basically traditional in conceptualization, pictorial and graphical rendering of forms, ${ }^{, 28}$ is also in accord with this postulation when he asserts graciously:

His (Ibigbami's) approach equally has enjoyed the admiration of his secondary students (those former students who specialized in areas such as painting, print making, textiles design, graphics design and sculpture but took ceramics design not as a concentration area but as an elective subject). It could be argued that the occasional romance of clay and the use of clay and mud in the works of Chief Tola Wewe, Dr. Kunle Filani, Prof Moyo Okediji and Prof Bolaji Campbell represent a great homage to Ibigbami's pedagogy. ${ }^{29}$

Surprisingly, Ibigbami's academic accomplishments were not limited to the studio art practice of pottery and ceramic sculpture. He was also a good scholar, whose body of scholarly essays on Yoruba culture, especially the traditional pottery related topics that were based on his continuous field trips to pottery centers all over the Yorubaland, have appeared in many academic journals. They included the following. "The Sacred Images of Ogun in Ire Ekiti," In Odu (Ile-Ife) 16, July 1977, 104-110; "Yoruba Traditional Pottery: Its Ritual Context and Use," In The Nigerian Field (Ibadan) 43, 3, September 1978, 127-132; "Ogun Festival in Ire-Ekiti," In Nigeria Magazine (Lagos) 126-127, 1979, 44-59; "Yoruba Pottery Firing," In Ceramic Review (London) 61, January 1980, 10-12; “Traditional Pottery in Yoruba Culture," In the Black

28 See Akintonde, 2013, p. 142.

29 See Babatunde Nasiru, "Ode to 'father' of modern Nigerian ceramics," In The Nation, 14 October 2020. 
Orpheus (Lagos) 4 (1), 1981, 12-19; "Some Socio-Economic Aspects of Pottery Among the Yoruba Peoples of Nigeria," In Earthenware in Asia and Africa (A Colloquium held 21-23 June 1982), edited by John Picton. London, University of London: Percival David Foundation for Chinese Art, 1984, 106117; "The Pot as a Vehicle," Folklore and National Development, Fourth Annual Congress of the Nigerian Folklore Society, 1985, 574-598 [unpublished], and 'The Art of Packing Ceramics and Pottery," Kurio Africana, Journal of Art and Criticism (Ile-Ife) 1 (1), 1989, 104-108. ${ }^{30}$

Bearing in mind that he was the very first person to be awarded the Master of Fine Arts terminal degree in Ceramics in Nigeria (Ahmadu Bello University, 1971). Added to all his accomplishments, particularly in the Ceramic Programme of the Ife Art School. This continued to be the standard with which the Ceramics Programme in the rest of Nigeria's Fine Arts Schools are being measured, it is not an overstatement to declare the late Chief Raphael Ige Ibigbami as the 'Father' of Modern Nigerian Ceramic art.

\section{Bibliography}

Abiodun, Rowland. Yoruba Art and Language: Seeking the African in African Art. New York: Cambridge University Press.2014.

Aig-Imoukhuede, Frank.. Evolution in Nigerian Art Series 2: The Ife Art School, 1974-1984 (Catalogue of an exhibition by students of the Department of Fine-Arts, University of Ife, Ile-Ife, Nigeria, held at the Exhibition Centre, National Council for Arts and Culture, Iganmu, Lagos, Nigeria, April 27-May 19, 1984). Lagos: National Council for Arts and Culture, Lagos Publishing. 1984.

Ainsworth, Mary.. Infancy in Uganda: Infant Care and the Growth of Love. Baltimore, MD: Johns Hopkins University Press. 1967.

Akintonde, Moses A.. "Repositioning Ceramic Professionalism in Art Training in Nigerian Tertiary Institution," Journal of Education and Practice, Vol. 4 no.16 (2013):136-144.

Akintonde, M.A., Emmanuel Akinde, Oladapo Abiodun, and Adeyinka Okunade.

"Outdoor Pottery Sculpture in Ife Art School," Academic Journal of Interdisciplinary Studies, Vol. 4 no. 3 (2015): 219-232.

Amherst College, MA 01002 (Website). "Rowland O. Abiodun," Faculty and Staff., accessible at: https://www.amherst.edu/people/facstaff/roabiodun. (October 1,

30 "Biography of Chief Raphael Ige Ibigbami" (n/d, unpublished). Also see "IBIGBAMI, Ige," In Biographical Legacy \& Research Foundation, Nigeria: Blerf's WHO'S WHO IN NIGERIA (online): https://blerf.org/index.php/biography/ibigbami-ige/ 
2020)

Bowlby, John. Attachment and Loss (Volume 1): Attachment. New York: Basic Books Press. 1969.

Crowder, Michael. "Institute of African Studies, Ife," The Journal of Modern African Studies, Vol. 7 no. 3 (October 1969): 513-515.

Editor's Desk. "Michael Crowder," Journal of African History, Vol. 29. no. 3, I-II (1983):1-2.

Editor, Notes and News. "University of Ife: Institute of African Studies." Africa: Journal of the International Institute (Published by Cambridge University Press) Vol. 41, no. 1(1971):57-63.

LaDuke, Betty.. Africa: Through the Eye of Women Artists, New Jersey: Africa World Press, Inc. 1991.

Lawal, Babatunde. "The Present State of Art Historical Research in Nigeria: Problems and Possibilities," Journal of African History (Published by Cambridge University Press), Vol. 18, no 2 (1977): 193-216.

Mission, Vision and The Foundation of the Obafemi Awolowo University (OAU), Ile-Ife, accessible at the University website: https://oauife.edu.ng/ (October 20, 2020)

Nasiru, Tunde.. "Ode to 'father' of modern Nigerian ceramics," In The Nation, accessible at https://thenationonlineng.net/ode-to-father-of-modern-nigerian-ceramics/. (14 October 2020).

Ojo. J.R.O. Museum of the Institute of African Studies, University of Ife: A Short-Illustrated Guide, Ile-Ife: University of Ife Press. 1969.

Omojolomoju, Olajide. "Contentment was watchword in our days - Pa Ibigbami," Interview with Chief Raphael Ige Ibigbami. In Leadership Newspaper, accessible at https://leadership.ng/ contentment-was-watchword-in-our-days-pa-ibigbami/2018.

Osso, Nyaknno. (n/d). "Folarin, Agbo," Biographical Legacy \& Research Foundation, Nigeria: Blerf's Who's Who in Nigeria (online), accessible at: https://blerf.org/index.php/biography/folarin-gbo/ (November 5, 2020) Osso, Nyaknno. (n/d). "IbigbamI, Ige," Biographical Legacy \& Research Foundation, Nigeria: Blerf's Who's Who in Nigeria (online), accessible at: https://blerf.org/index.php/biography/ibigbami-ige/ (November 5, 2020)

Osso, Nyaknno. (n/d). “OJO, John Rowland Oluwafemi,” Biographical Legacy \& Research Foundation, Nigeria: Blerf's Who's Who in Nigeria (online), accessible at: https://blerf.org/index.php/biography/ojo-john-rowland-oluwafemi/(November 5, 2020)

Osso, Nyaknno. (n/d). "Wangboje, Professor Solomon Ona Irein," Biographical Legacy \& Research Foundation, Nigeria: Blerf's Who's Who in Nigeria (online), accessible at: https://blerf.org/index.php/biography/wangboje-professor-solomon-ona-irein/ (November 5, 2020) 
Virginia Commonwealth University, Richmond, Virginia 23284-3046 (Website). "Babatunde

Lawal," Faculty Bio, accessible at: https://web.archive.org/ web/20140523102325/http://arts.vcu.edu/arthistory/faculty-bio/ babatunde-lawal/ 